\title{
Distinct NMDA Receptor Subpopulations Contribute to Long-Term Potentiation and Long-Term Depression Induction
}

\author{
Sabina Hrabetova, ${ }^{1}$ Peter Serrano, ${ }^{1}$ Nancy Blace, ${ }^{1}$ Heong W. Tse, ${ }^{2}$ Donald A. Skifter, ${ }^{3}$ David E. Jane, ${ }^{2}$ \\ Daniel T. Monaghan, ${ }^{3}$ and Todd Charlton Sacktor ${ }^{1}$
}

'Laboratory of Molecular Neuroscience, Departments of Physiology, Pharmacology, and Neurology, State University of New York, Downstate Medical Center, Brooklyn, New York 11203, 2Department of Pharmacology, University of Bristol, School of Medical Sciences, Bristol BS81TD, United Kingdom, and ${ }^{3}$ Department of Pharmacology, University of

Nebraska Medical Center, Omaha, Nebraska 68198

Long-term potentiation (LTP) and long-term depression (LTD) are persistent modifications of synaptic strength that have been implicated in learning, memory, and neuronal development. Despite their opposing effects, both forms of plasticity can be triggered by the activation of NMDA receptors. One mechanism proposed for this bidirectional response is that the specific patterns of afferent stimulation producing LTP and LTD activate to different degrees a uniform receptor population. A second possibility is that these patterns activate separate receptor subpopulations composed of different NMDA receptor (NR) subunits. To test this hypothesis we examined the inhibition of LTP and LTD by a series of competitive NMDA receptor antagonists that varied in their affinities for NR2A/B and NR2C/D subunits. The potency for the inhibition of LTP compared with inhibition of LTD varied widely among the agents. Antagonists with higher affinity for NR2A/B subunits relative to NRC/D subunits showed more potent inhibition of LTP than of LTD. D-3-(2-carboxypiperazine-4-yl)-1-propenyl-1-phosphonic acid, which binds to NR2A/B with very high affinity relative to NR2C/D, showed an 1000-fold higher potency for LTP than for LTD. These results show that distinct subpopulations of NMDA receptors characterized by different NR2 subunits contribute to the induction mechanisms of potentiation and depression.

Key words: NMDA; NR2 subunit; long-term potentiation; longterm depression; D-3-(2-carboxypiperazine-4-yl)-1-propenyl-1phosphonic acid; D-2-amino-5-phosphonovaleric acid; (士)-cis-1(phenanthren-2-yl-carbonyl)piperazine-2,3-dicarboxylic acid
In the hippocampal CA 1 region and the cerebral cortex, both long-term potentiation (LTP) and long-term depression (LTD) can depend on the activation of NM DA receptors, because both can be blocked by the N M DA receptor antagonist D/L-2-amino5-phosphonovaleric acid (D/L-A P5) (Collingridge et al., 1983; $\mathrm{H}$ arris et al., 1984; D udek and Bear, 1992; M ulkey and M alenka, 1992; K irkwood et al., 1993; Christie et al., 1996; C ummings et al., 1996). H igh-frequency stimulation causes strong activation of the ligand- and voltage-dependent N M D A receptors and a large influx of $\mathrm{Ca}^{2+}$ into postsynaptic neurons to trigger potentiation. $\mathrm{L}$ ow-frequency stimulation results in moderate activation of NMDA receptors and a moderate influx of $\mathrm{Ca}^{2+}$, leading to depression. A $n$ additional mechanism participating in this bidirectional response, however, may be that high- and low-frequency stimulation activate distinct subpopulations of N M DA receptors (H rabetova and Sacktor, 1997).

N M D A receptors consist of N M DA receptor 1 (N R 1) subunits and members of a family of glutamate-binding NR2 subunits (N R 2A -D) (I keda et al., 1992; M onyer et al., 1992; I shii et al., 1993). R ecombinant N M DA receptors that contain N R 1 subunits and subunits NR2A or $B$ require a strong depolarization to overcome $\mathrm{M} \mathrm{g}^{2+}$ blockade and have high conductances, and those

\footnotetext{
Received Feb. 7, 2000; revised M arch 29, 2000; accepted A pril 11, 2000.

This research was supported by G rants R 0157068 and R 29/R 0153576 from the National Institute of M ental H ealth (T.C.S.) and Grant 17-94-C -4050 from the US A rmy M edical R esearch Division (D.T.M .). We thank D r. J an $\mathrm{H}$ rabe for statistical analysis and Dr. Feng Bihua for assistance with autoradiograms. We thank Drs. Peter Bergold, Stanley Friedman, R obert M uller, Wayne Sossin, K eith W illiams, and R obert K. S. Wong for discussion and comments.

Correspondence should be addressed to Dr. Todd C. Sacktor, Laboratory of M olecular Neuroscience, Box 29, Departments of Physiology, Pharmacology, and N eurology, State U ni versity of N ew Y ork, D ownstate M edical C enter, 450 C larkson A venue, Brooklyn, N Y 11203. E-mail: TSA CK TOR @ netmail.hscbkyn.edu.

Dr. H rabetova's present address: Department of Physiology and Neuroscience, N ew Y ork U niversity M edical C enter, 550 First A venue, N ew Y ork, N Y 10016. Copyright (c) 2000 Society for N euroscience $0270-6474 / 00 / 200001-\bullet \$ 15.00 / 0$
}

with N R 2C or D need only modest depolarization to overcome $\mathrm{M} \mathrm{g}^{2+}$ blockade and show low conductances (M onyer et al., 1992, 1994). Native N M D A receptors containing N R 2D are estimated to form $\sim 10 \%$ of the N M D A receptor population in the cortex of adult rats (D unah et al., 1998), and levels of expression of the subunits are higher in juvenile animals (D unah et al., 1996; W enzel et al., 1996), when LTD can most efficiently be produced (D udek and Bear, 1993). CA 1 pyramidal cells express mR N A for N R 2A, 2B, and 2D in adult humans (Scherzer et al., 1998) and in juvenile rats (Kirson et al., 1999). Currents attributable to N M DA receptors containing N R 2D subunits have been observed in juvenile CA 1 pyramidal cells (K irson et al., 1999).

NMDA receptor subpopulations containing these different subunits can be distinguished by competitive N M DA receptor antagonists with different affinities to the glutamate-binding site of the various N R 2s (M onaghan et al., 1998). Comparisons of LTP and LTD using these antagonists, however, must take into account the receptor occupancies required for $L T P$ and $L T D$ induction, which are not known and may not be the same. LTP, for example, may require the agonist occupation of a high percentage of receptors for a large increase in postsynaptic $\mathrm{Ca}^{2+}$,

This article is published in The Journal of Neuroscience, R apid Communications Section, which publishes brief, peerreviewed papers online, not in print. R apid Communications are posted online approximately one month earlier than they would appear if printed. They are listed in the Table of Contents of the next open issue of J N eurosci. C ite this article as: J Neurosci, 2000, 20:RC81 (1-6). The publication date is the date of posting online at www.jneurosci.org.

http://ww w.jneurosci.org/cgi/content/full/4274 
Table 1. $K_{\mathrm{i}}$ values for recombinant NMDA receptors containing NR2 subunits A-D and $\mathrm{IC}_{50}$ values for LTP and LTD of the NMDA receptor antagonists PPDA, D-AP5, and D-CPPene

\begin{tabular}{|c|c|c|c|}
\hline & PPDA & D-A P5 & D-CPPene \\
\hline N R 2 A / N R $1 K_{\mathrm{i}}(\mu \mathrm{M})$ & $0.68 \pm 0.17$ & $0.28 \pm 0.02$ & $0.11 \pm 0.03$ \\
\hline N R 2B/N R $1 K_{\mathrm{i}}(\mu \mathrm{M})$ & $0.35 \pm 0.02$ & $0.46 \pm 0.14$ & $0.14 \pm 0.04$ \\
\hline N R 2 C / N R $1 K_{\mathrm{i}}(\mu \mathrm{M})$ & $0.070 \pm 0.015$ & $1.64 \pm 0.14$ & $1.46 \pm 0.08$ \\
\hline N R 2D / N R $1 K_{\mathrm{i}}(\mu \mathrm{M})$ & $0.108 \pm 0.032$ & $3.71 \pm 0.67$ & $1.84 \pm 0.74$ \\
\hline$(2 \mathrm{C}+2 \mathrm{D}) K_{\mathrm{i}} /(2 \mathrm{~A}+2 \mathrm{~B}) K_{\mathrm{i}}$ & 0.17 & 7.2 & 13.2 \\
\hline$(2 \mathrm{C}+2 \mathrm{D}) K_{\mathrm{i}} /(2 \mathrm{~A}+2 \mathrm{~B}) K_{\mathrm{i}}^{\text {nl PPDA }}$ & 1 & 42 & 78 \\
\hline $\operatorname{LTP} \mid \mathrm{C}_{50}(\mu \mathrm{M})$ & 0.29 & 0.014 & 0.022 \\
\hline LTD IC $C_{50}(\mu \mathrm{M})$ & 0.63 & 0.45 & 25.3 \\
\hline LTD IC $50 /$ LTP IC 50 & 2 & 32 & 1150 \\
\hline LTD IC ${ }_{50} / \mathrm{LTP} I \mathrm{C}_{50}^{\mathrm{nIPPDA}}$ & 1 & 16 & 575 \\
\hline
\end{tabular}

The rank order of decreasing affinity for recombinant $2 \mathrm{C} / \mathrm{D}$ receptors, relative to $2 \mathrm{~A} / \mathrm{B}$ receptors, matches the decreasing potency for LTD, relative to LTP. $K_{\mathrm{i}}$ values were obtained from N R 2 subunits recombinantly expressed with N R 1a subunits to form receptors in Xenopus 0ocytes. The $K_{\mathrm{i}}$ values for D-A P5 and D-C PPene are from Buller and M onaghan (1997) (mean \pm SEM ; $n=4-6$ ); the $K_{\mathrm{i}}$ values for PPDA were from B. Feng, H. W. Tse, D. A. Skifter, D. E. J ane, and D. T. $\mathrm{M}$ onaghan (unpublished data) $(n=3)$. D ifferences among the agents were expressed by normalization to PPDA [(2C $+2 \mathrm{D})$ $K_{\mathrm{i}} /(2 \mathrm{~A}+2 \mathrm{~B}) K_{\mathrm{i}}^{\mathrm{nI} P \mathrm{PPA}}$ and LTD IC 50 /LTPIC ${ }_{50}^{\text {nI PPDA }}$ ], obtained by dividing the ratios for each drug by the ratio for PPDA.

whereas LTD might require occupation of only a few receptors for a modest rise in $\mathrm{Ca}^{2+}$ (Lisman, 1989; A rtola and Singer, 1993; $\mathrm{H}$ ansel et al., 1997; $Y$ ang et al., 1999). If this were the case, more receptors would need to be blocked to prevent depression than potentiation, and all NMDA receptor antagonists would show a higher $I C_{50}$ for LTD than for LTP. When comparing antagonists that vary in their N R 2 subunit selecti vity, the ratio of LTD IC 50 to LTP IC 50 would be similar for all agents if a single receptor subtype mediated both forms of plasticity but would differ if specific subunits selectively contributed to LTP or LTD.

In this study, we find large differences in the potencies of the antagonists for inhibition of LTP and LTD, indicating that NM DA receptors with distinct subunit compositions contribute to the induction mechanisms of LTP and LTD.

Portions of this paper were published previously in abstract form (H rabetova et al., 1998).

\section{MATERIALS AND METHODS}

Immunoblots. I mmunoblots of membrane fractions from rat CA 1 regions at different developmental ages were performed as previously described (H rabetova and Sacktor, 1996). R abbit antiserum to N R 2A / B (used at 1:1000) was a generous gift from Dr. R. . . Wenthold (National Institutes of Health, Bethesda, M D); rabbit antiserum to NR2D (1:50) was a generous gift from Dr. B. B. Wolfe (Georgetown U niversity School of M edicine, Washington, DC); rabbit antisera to N R 2C (1:200) was from Chemicon (Temecula, CA). Total protein per lane was: N R 2A / B 10 $\mu \mathrm{g} /$ lane; $2 \mathrm{C}, 40 \mu \mathrm{g} /$ lane for CA 1, $50 \mu \mathrm{g} /$ lane for thalamus, and 30 $\mu \mathrm{g} /$ lane for cerebellum; and $2 \mathrm{D}, 40 \mu \mathrm{g} /$ lane.

In situ hybridization. N R 2D MR NA was visualized as previously described (Buller et al., 1994). Freshly frozen Sprague Dawley rat (11-dold) brains were sectioned (12 $\mu \mathrm{m})$, thaw-mounted, and fixed for $5 \mathrm{~min}$ in $4 \%$ paraformaldehyde at $4^{\circ} \mathrm{C}$. A fter ethanol dehydration, a $45 \mathrm{mer}$ ${ }^{35} \mathrm{~S}$-labeled antisense N R 2D (5'-C TCCGAATCC TCG GA GTCCGAAG GCGAAGGCTCGA GGTCCAGGTA-3'), complementary to sequences encoding amino acids 1067-1081 of the $\epsilon 4$ subunit (I keda et al., 1992), was dissolved in hybridization buffer $(2000 \mathrm{cpm} / \mu \mathrm{l}, \sim 0.2 \mathrm{~nm}$; New England Nuclear, Boston, M A) containing $0.2 \mathrm{M}$ dithiothreitol and applied to sections for overnight incubations under Parafilm-sealed coverslips at $42^{\circ} \mathrm{C}$ and then washed for $20 \mathrm{~min}$ at a final stringency of $1 \times$ SSC $(0.015$ $\mathrm{M}$ sodium citrate and $0.15 \mathrm{M} \mathrm{NaCl}$ ) at $60^{\circ} \mathrm{C}$. Sections were air-dried and exposed to film ( $\beta M$ ax; A mersham, A rlington Heights, IL). Probe specificity was confirmed by incubation of the radiolabeled oligonucleotides with $100 \mathrm{~nm}$ unlabeled probe (data not shown).

In vitro transcription and translation in $\mathrm{X}$ enopus oocytes. R N A translation and transcription in Xenopus oocytes and electrophysiological recordings were performed as previously described (M onaghan and $L$ arson, 1997). CDNA encoding the N R la subunit was a generous gift from Dr. S. Nakanishi (K yoto U niversity, F aculty of M edicine, K yoto, Japan); N R 2A, N R 2C, and N R 2D subunits were generous gifts from $D r$. P. Seeburg (U niversity of $\mathrm{H}$ eidelberg, $\mathrm{H}$ eidelberg, G ermany); N R 2B was generously provided by Dr. D. Pritchett and Dr. D. Lynch (U niversity of
Pennsylvania, Philadelphia, PA). Plasmids were linearized with Notl (NR 1a), EcoRI (NR2A, NR2C, and NR2D), or Sall (NR2B) and transcribed in vitro using the $\mathrm{mM}$ essage $\mathrm{mM}$ achine $\mathrm{RNA}$ polymerase transcription kit (A mbion, A ustin, TX). NR la was mixed 1:3 with $N R 2 A, N R 2 B, N R 2 C$, or N R 2D R NA, and 2-50 ng of this mixture was injected into oocytes. A gonist-evoked responses were measured using a standard two-microelectrode voltage clamp (model OC-725B O ocyte C lamp; W arner Instruments, $\mathrm{H}$ amden, C T) at a holding potential of -60 $\mathrm{mV}$. Glutamate $(10 \mu \mathrm{M})$ and glycine $(10 \mu \mathrm{M})$ were applied until stable plateau responses were obtained; ( \pm )-cis-1-(phenanthren-2yl-carbonyl)piperazine-2,3-dicarboxylic acid (PPDA) $(0.1,0.3,1,3,10$, or $30 \mu \mathrm{M})$ was then applied until steady-state blockade was obtained, followed by antagonist washout and full agonist responses. Current responses were captured and analyzed with A xoD ata (A xon Instruments, Foster C ity, CA) and GraphPad Prism (ISI Software, San Diego, CA) software. K. values were corrected for agonist affinity according to the Cheng-Prusoff equation. $D$ ata in Table 1 are expressed as mean $K_{\mathrm{i}} \pm$ SE M

PPDA was found to have little effect on native non-N M D A glutamate receptors. Autoradiography, performed as described by Monaghan (1993), showed that at $10 \mu \mathrm{M}$, PPDA inhibited $44.6 \pm 1.3 \%$ of $100 \mathrm{~nm}$ $\left[{ }^{3} \mathrm{H}\right] \mathrm{C}$ N QX binding to native A M PA receptors and $9.3 \pm 6.7 \%$ of $25 \mathrm{nM}$ ${ }^{3} \mathrm{H}$ ]kainate $(n=3)$.

Electrophysiology. Transverse hippocampal slices $(450 \mu \mathrm{m})$ were prepared as previously described ( $\mathrm{H}$ rabetova and Sacktor, 1996). Briefly, Sprague Dawley rats (16-21 d) were anesthetized with halothane and decapitated. The hippocampi were dissected, bathed in cold saline, and sliced with a M cl Iwain tissue slicer. Slices were placed in an interface recording chamber and kept for $30 \mathrm{~min}$ in a saline solution containing 125 $\mathrm{mm} \mathrm{NaCl}, 2.5 \mathrm{~mm} \mathrm{KCl}, 1.25 \mathrm{~mm} \mathrm{NaH}_{2} \mathrm{PO}_{4}, 26 \mathrm{~mm} \mathrm{NaHCO}_{3}, 11 \mathrm{~mm}$ glucose, $10 \mathrm{mM} \mathrm{M} \mathrm{gCl}$, and $0.5 \mathrm{mM} \mathrm{CaCl}$, pH 7.4 , equilibrated with $95 \%$ $\mathrm{O}_{2}$ and $5 \% \mathrm{C} \mathrm{O}_{2}$ at $32^{\circ} \mathrm{C}$. The slices were then perfused with the saline solution containing $1.2 \mathrm{M} \mathrm{gCl}_{2}$, and $1.7 \mathrm{~mm} \mathrm{CaCl}$. Test stimuli ( 100 $\mu \mathrm{sec})$ were delivered every $15 \mathrm{sec}$ through bipolar tungsten electrodes placed across the Schaffer collateral-commissural fibers. Field EPSPS were recorded using glass microelectrodes filled with the saline solution (resistance, 5-10 M $\Omega$ ) and placed in CA 1 stratum radiatum. The current intensity of test stimuli $(25-50 \mu \mathrm{A})$ was set to produce half-maximal E PSPs (2-3 mV ). The baseline was recorded for at least $10 \mathrm{~min}$ to ensure the stability of the response. LTP was induced by a $100 \mathrm{H} \mathrm{z}, 1 \mathrm{sec}$ train at a current set to produce $75 \%$ of the maximal EPSP response. LTD was induced by $3 \mathrm{~Hz}$ stimulation for $5 \mathrm{~min}$ at the current intensity of the test stimulus. Data were collected and analyzed using Superscope (GW Instrument, Somerville, M A). The slope of the field E PSP was measured beginning at $10 \%$ and ending at $50 \%$ of the initial phase of the EPSP response. PPDA was synthesized by a method that will be published elsewhere; D-A P 5 was obtained from Tocris Cookson (St. L ouis, M O); D-3-(2-carboxypiperazine-4-yl)-1-propenyl-1-phosphonic acid (D-C PPene) was a generous gift from N ovartis (Berne, Switzerland). The compounds were added to the bath at least $40 \mathrm{~min}$ before the induction of LTP or LTD. Dose-response curves for the effect of NM DA receptor antagonists on the efficacy of LTP and LTD were fitted ( $M$ athematica; W ol fram R esearch, Inc., C hampaign, IL ) according to the equation $E=E_{\max }-$ $E_{\max } /\left[1+\left(I C_{50} / A\right)^{n}\right]$, where $E$ is the efficacy of LTP or LTD in the presence of antagonist, $E_{\max }$ is the control efficacy of LTP or LTD in the absence of antagonist, I $I C_{50}$ is the concentration of antagonist half inhib- 
iting the maximal response, $A$ is the antagonist concentration, and $n$ is the $\mathrm{H}$ ill coefficient.

\section{RESULTS}

To establish the presence of the various N R 2 subunits in the CA 1 region of the rat hippocampus, we first examined the developmental expression of the subunits by immunoblot. The expression of N R 2A / B increased during development from juvenile to adult ages (Fig. 1A). In contrast, N R 2D was maximal at 2 weeks and declined slightly in adulthood (Fig. $1 A$ ), a result consistent with other reports of N R 2D protein levels in whole rat brain (Wenzel et al., 1996) and telencephalon (D unah et al., 1996). L ow levels of $2 \mathrm{C}$ protein were also found in the CA 1 of juvenile animals (Fig. $1 A$ ). The expression of the N R 2D mRNA was localized to the CA 1 pyramidal cell layer by in situ hybridization (Fig. 1B).

A series of NMDA receptor antagonists that differ in their binding affinities for NR2A / B and NR2C/D subunits, PPDA, D-A P-5, and D-C PPene, was then used to examine LTP and LTD induction (Table 1). LTP was induced by a single train of $100 \mathrm{~Hz}$ lasting $1 \mathrm{sec}$ applied to Schaffer collateral-commissural fibers in the CA 1 region of the hippocampus, and LTD was produced by 3 $\mathrm{H}$ z stimulation for 5 min (Fig. $2 A$ ). The effect on synaptic transmission was measured as a change in the initial slope of EPSPS recorded extracellularly in stratum radiatum. Without antagonists, $30 \mathrm{~min}$ after the $100 \mathrm{~Hz}$ stimulation, the synaptic responses were $168.9 \pm 7.5 \%$ of baseline (set at $100 \% \pm$ SE M ; Fig. $2 A$ ). Thirty minutes after the $3 \mathrm{~Hz}$ stimulation, the synaptic efficacy decreased to $65.5 \pm 3.9 \%$ of baseline (Fig. $2 A$ ). For each dose of antagonist examined, we demonstrated normal LTP or LTD in adjacent slices from the same hippocampus in physiological saline, as controls. Inhibition was determined as the difference in potentiation or depression at $30 \mathrm{~min}$ in the presence and absence of the drug $(n=$ 4- 6 slices for each drug concentration and for paired controls).

PPDA is an NMDA receptor antagonist with 3- to 10-fold higher affinity for recombinant NR2C/D subunits than for N R 2A / B subunits (Table 1). N either LTP nor LTD was blocked with $0.1 \mu \mathrm{MA}$ 

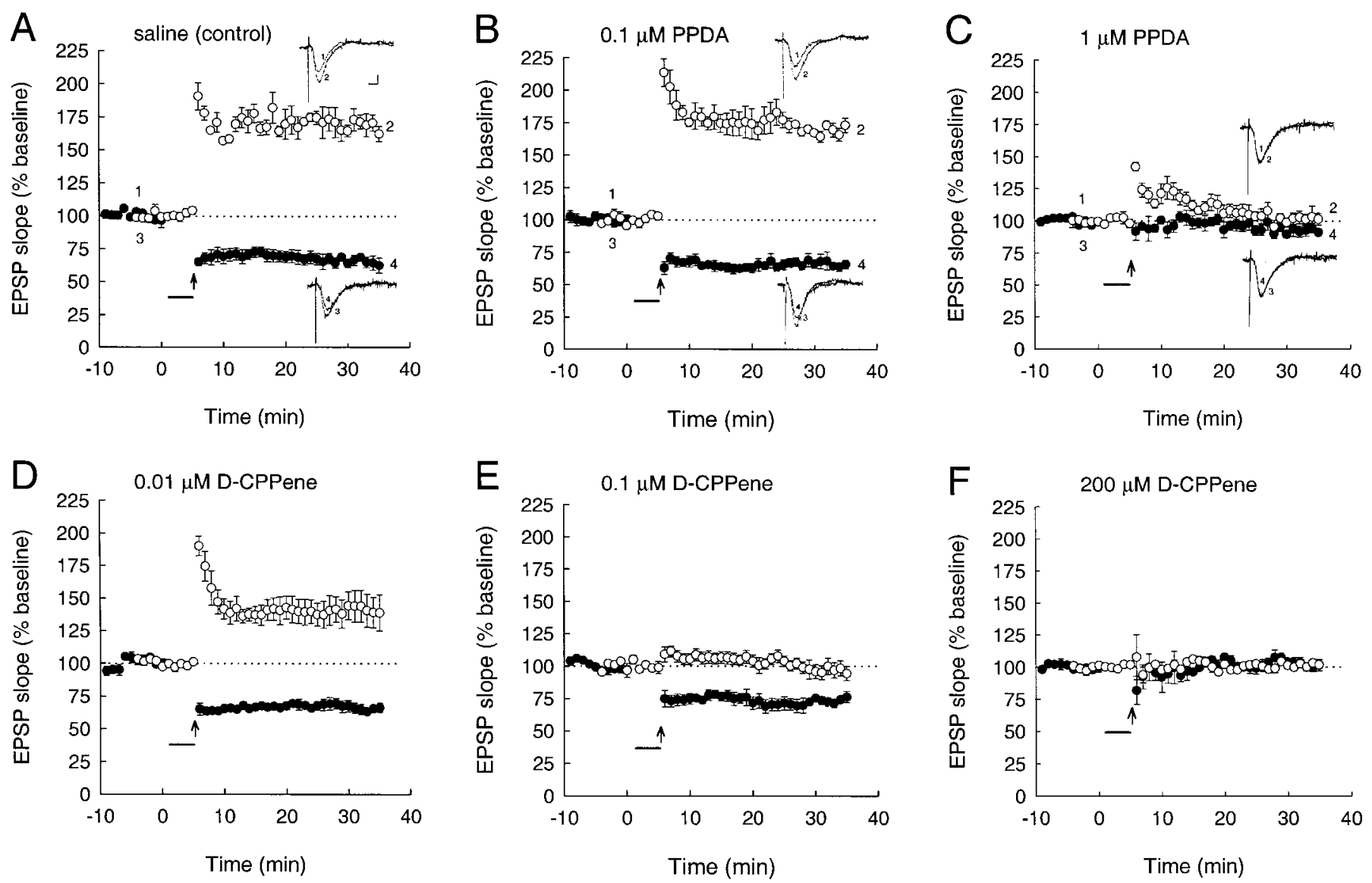

Figure 2. Dose responses for LTP and LTD induction of the NM DA receptor antagonists PPDA, D-A P5, and D-C PPene. R epresentative field EPSPS correspond to numbered points in the time courses (calibration: $1 \mathrm{mV}$ vertically, $5 \mathrm{msec}$ horizontally). A, LTP (open circles) is induced by $100 \mathrm{~Hz}$ stimulation lasting $1 \mathrm{sec}$ (arrow). LTD (closed circles) is induced by $3 \mathrm{~Hz}$ stimulation applied for 5 min (short horizontal bar). B, $0.1 \mu \mathrm{M}$ PPD A does not alter LTP or LTD. C, $1 \mu \mathrm{M}$ PPD A blocks both LTP and LTD. D, $0.01 \mu \mathrm{M}$ D-C PPene does not block the induction of LTP or LTD. E, $0.1 \mu \mathrm{M}$ D-C PPene blocks LTP but has no effect on LTD.F, $200 \mu \mathrm{M}$ D-C PPene blocks both LTP and LTD. Field EPSPs are normalized to baseline set at $100 \% \pm$ SE M ; $n=4-6$ for all experiments.

tivation of conventional N R 2A / B-containing N M DA receptors, which require high-frequency stimulation to overcome their high degree of $\mathrm{M} \mathrm{g}^{2+}$ block, contribute to LTP, whereas N R 2C/D-containing $\mathrm{NM}$ DA receptors, which require relatively low levels of depolarization to overcome their $\mathrm{M} \mathrm{g}^{2+}$ block (M onyer et al., 1992, 1994), contribute to LTD. O ur results are consistent with earlier observations that the NM DA receptor antagonists $(5 R, 10 S)-(+)$ 5-methyl-10-11-dihydro-5H -dibenzo[a,d]cyclohepten-5,10-imine (M K 801) and 3-(( $R, S)$-2-carboxypiperazin-4-yl)propyl-1-phosphonic acid (CPP), both of which have a preference for N R 2A /B over N R 2C /D subunits (Beaton et al., 1992; Buller et al., 1994), effectively block LTP (A braham and M ason, 1988; M ayford et al., 1995) but do not generally block LTD (Mayford et al., 1995; $\mathrm{H}$ rabetova and Sacktor, 1997) (although see Heynen et al., 1996). Because the stoichiometry of subunits in native N M DA receptors is not yet known, different ratios of the N R 2 subunits may determine the distinct receptor subpopulations contributing to potentiation and depression.

The differences in LTD/LTP IC ${ }_{50}$ values among the series of agents was large. F or D-C PPene, the magnitude of the difference in LTD and LTP IC ${ }_{50}$ values was greater than that of the difference in affinities for the recombinantly expressed receptors ( $\mathrm{Ta}$ ble 1). This is likely because of a stronger ability of the agent to distingui sh subunits in their native states compared with subunits that are expressed recombinantly. For example, the binding of $\mathrm{D}-\mathrm{C} P$ Pene to low-affinity sites in the cerebellum, attributable to native NR2C -containing receptors, has a $K_{\mathrm{i}}$ of $14.3 \pm 3.6 \mu \mathrm{M}$
(Buller et al., 1994), whereas its binding to high-affinity native sites, attributable to N R 2A-containing receptors, has a $K_{\mathrm{i}}$ of $0.25 \pm 0.06 \mu \mathrm{m}$. PPDA has a $K_{\mathrm{i}}$ of $0.39 \mu \mathrm{m}$ to these native $2 \mathrm{C}$ receptors and $7.2 \mu \mathrm{M}$ to the native $2 A$ receptors (D. T. M onaghan, unpublished observations). This would result in a 1057-fold difference between D-C PPene and PPDA in the ability to distinguish these native receptors ([ $\left.K_{\mathrm{i}}{ }^{\mathrm{D}-\mathrm{CPP} e n e} 2 \mathrm{C} / K_{\mathrm{i}}{ }^{\mathrm{D}-\mathrm{CPP} \text { PPene}} 2 \mathrm{~A}\right] /$ $\left.\left[K_{\mathrm{i}}^{\mathrm{PPDA}} 2 \mathrm{C} / K_{\mathrm{i}}^{\mathrm{PPDA}} 2 \mathrm{~A}\right]\right)$, comparable with the 575 -fold difference in LTD/LTP IC 50 values observed for the two agents. These differences between native and recombinant receptors, likely to arise from subunit composition and post-translational modifications (Grimwood et al., 1993), may also contribute to the differences in the absolute values between the $K_{\mathrm{i}}$ values for the recombinant receptors and the $I C_{50}$ values of $L T D$ and $L T P$.

A lthough D-C PPene showed orders of magnitude difference in LTD and LTP potencies, PPDA, the antagonist with the strongest preference for NRC/D subunits tested, still showed a twofold higher $I C_{50}$ for LTD than for LTP. The absolute $I C_{50}$ values, however, may be determined, in part, by differences in the occupancy of receptor subpopulations required for LTP and LTD induction, such that a higher percentage of N R 2C/D-containing receptors must be blocked to prevent $L T D$, and a lower percentage of N R 2A / B-containing receptors must be blocked to prevent LTP.

The contribution of N R 2 C /D -containing receptors to synaptic depression was observed with both low-frequency afferent stimulation and high-frequency stimulation in which LTP was prevented by the N R 2A / B-selective antagonist D-C PPene (Fig. 4). A 

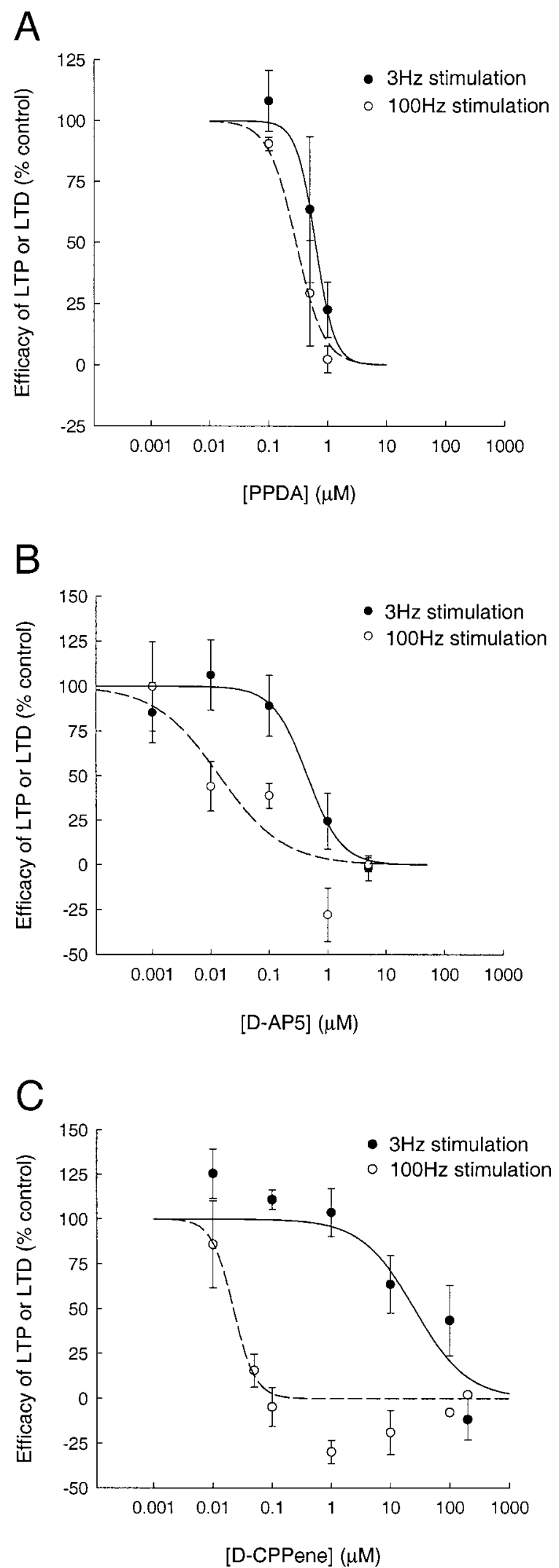

Figure 3. PPDA, D-A P5, and D-CPPene have different $L T D / L T P I C{ }_{50}$ ratios. $A$, PPD A shows a similar IC $\mathrm{C}_{50}$ for $3 \mathrm{~Hz} \mathrm{LTD}$ (closed circles) and 100 $\mathrm{H}$ z LTP (open circles). B, D-A P5 has a moderately higher IC ${ }_{50}$ for LTD than for LTP. C, D-C PPene shows a $\sim 1000$-fold higher IC ${ }_{50}$ for LTD than for LTP.

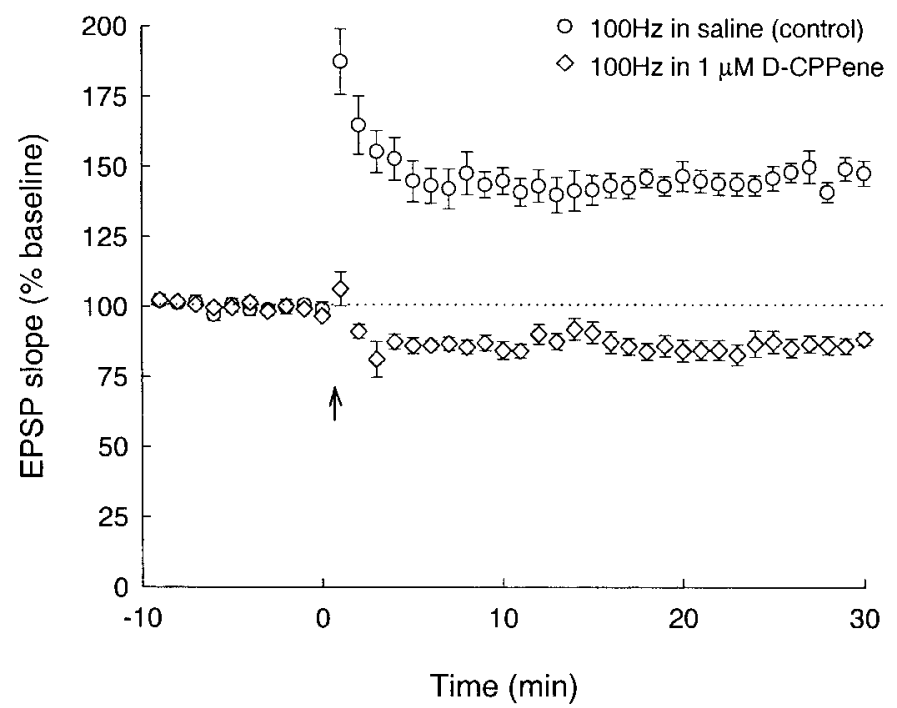

Figure 4. High-frequency, $100 \mathrm{~Hz}$ stimulation produces LTD in the presence of $1 \mu \mathrm{M}$ D-C PPene (open diamonds; $n=8$ ), a concentration that blocks $100 \mathrm{~Hz}$ LTP but not $3 \mathrm{~Hz}$ LTD. Control LTP in adjacent hippocampal slices was observed in drug-free saline (open circles).

nearly identical result has been reported for adult rats injected with moderate doses of CPP, in which prime-burst, highfrequency stimulation used to induce in vivo hippocampal LTP was found to produce in vivo LTD (Kentros et al., 1998). A similar result was also obtained in slices bathed in a moderate dose of D-AP5, in which tetanic stimulation that normally produces LTP was found to produce LTD (Cummings et al., 1996). These results are consistent with the interpretation that low-frequency stimulation initiates the molecular mechanisms only for depression, whereas high-frequency stimulation activates the mechanisms of both potentiation and depression, but the former masks or outweighs the latter.

Our results show that the molecular mechanisms of potentiation and depression diverge at the very beginning of postsynaptic signal transduction through distinct N M DA subpopulations. Differences in conductances and the duration of opening between two receptor populations may contribute to the regulation of postsynaptic $\mathrm{Ca}^{2+}$ influx in the induction of LTP and LTD (L isman, 1989; A rtola and Singer, 1993; M alenka, 1994; $\mathrm{H}$ ansel et al., 1997). The relatively low conductance for cations and the long duration of opening of the 2D channel (M onyer et al., 1994), for example, may permit the modest but prolonged $\mathrm{Ca}^{2+}$ influx that has been reported to be required to trigger the induction of LTD ( $Y$ ang et al., 1999). O ur results do not indicate the mechanism by which distinct NM DA subpopulations produce particular signal transduction pathways, leading ultimately to persistent strengthening or weakening of synaptic efficacy. T wo hypotheses offer equally plausible mechanisms. $\mathrm{Ca}^{2+}$ signals produced by the different receptor populations may result in different biochemical pathways based only on their concentration and time course. A Iternatively, these signals may have unique spatiotemporal properties and preferential access to particular downstream signaling molecules. NR2C and 2D, for example, possess a proline-rich intracellular C -terminal domain (I keda et al., 1992; Ishii et al., 1993), which, in the case of 2D, allows for the selective association with the Src homology 3 domain of C-A BL kinase (D. M onaghan, personal communication). By dividing the functions of the N M DA receptor into two distinct receptor subpopulations, LTP and LTD induction can be independently regulated, increasing the flexibility of the bidirectional regulation of synaptic strength. 


\section{REFERENCES}

A braham WC, M ason SE (1988) Effects of the N M D A receptor/channel antagonists CPP and M K 801 on hippocampal field potentials and long-term potentiation in anesthetized rats. Brain R es 462:40 - 46.

A rtola A , Singer W (1993) L ong-term depression of excitatory synaptic transmission and its relationship to long-term potentiation. Trends Neurosci 16:480-487.

Beaton J A, Stemsrud K, M onaghan DT (1992) Identification of a novel $N$-methyl-D-aspartate receptor population in the rat medial thalamus. Neurochem 59:754-757.

Buller AL, M onaghan DT (1997) Pharmacological heterogeneity of N M DA receptors: characterization of N R 1a/N R 2D heteromers expressed in Xenopus 0ocytes. Eur J Pharmacol 320:87-94.

Buller A, L arson $H$, Schneider B, B eaton J, M orrisett R, M onaghan D (1994) The molecular basis of N M DA receptor subtypes: native receptor diversity is predicted by subunit composition. J Neurosci 14:5471-5484.

Christie BR, M agee J C, J ohnston D (1996) The role of dendritic action potentials and $\mathrm{Ca}^{2+}$ influx in the induction of homosynaptic long-term depression in hippocampal CA1 pyramidal neurons. Learn Mem 3:160-169.

Collingridge GL, K ehl SJ , M CL ennan H (1983) E xcitatory amino acids in synaptic transmission in the Schaffer collateral-commissural pathway of the rat hippocampus. Physiol (L ond) 334:34-46.

Cummings J A, M ulkey R M, Nicoll R A, M alenka R C (1996) C $\mathrm{a}^{2+}$ signaling requirements for long-term depression in the hippocampus. Neuron 16:825-833.

D udek SM, B ear M F (1992) H omosynaptic long-term depression in area CA 1 of hippocampus and effects of $N$-methyl-D-aspartate receptor blockade. Proc Natl A cad Sci U SA 89:4363- 4367.

Dudek SM, Bear M F (1993) Bidirectional long-term modification of synaptic effectiveness in the adult and immature hippocampus. J Neurosci 13:2910-2918.

D unah AW, Y asuda R P, W ang Y H, L uo I, D avila-G arcia M, G badegesin M, Vicini S, Wolfe BB (1996) R egional and ontogenic expression of the NMDA receptor subunit NR2D protein in rat brain using a subunit-specific antibody. J Neurochem 67:2335-2345.

D unah AW, L uo J, Wang Y H, Y asuda R P, Wolfe BB (1998) Subunit composition of $N$-methyl-D-aspartate receptors in the central nervous system that contain the N R 2D subunit. M ol Pharmacol 53:429-437.

Grimwood S, Wilde GJC, Foster AC (1993) Interactions between the glutamate and glycine recognition sites of the $N$-methyl-D-aspartate receptor from rat brain, as revealed from radioligand binding studies. Neurochem 60:1729-1738.

$\mathrm{H}$ ansel C, A rtola A, Singer W (1997) Relation between dendritic $\mathrm{Ca}^{2+}$ levels and the polarity of synaptic long-term modifications in rat visual cortex neurons. Eur I N eurosci 9:2309-2322.

$\mathrm{H}$ arris $\mathrm{EW}, \mathrm{G}$ anong $\mathrm{A} \mathrm{H}$, C otman C W (1984) L ong-term potentiation in the hippocampus involves activation of $N$-methyl-D -aspartate receptors. Brain R es 323:132-137.

H eynen A J, A braham W C, Bear M F (1996) Bidirectional modifications of CA 1 synapses in the adult hippocampus in vivo. N ature 381:163-166.

$\mathrm{H}$ rabetova S, Sacktor TC (1996) Bidirectional regulation of protein kinase $M \zeta$ in the maintenance of long-term potentiation and long-term depression. J Neurosci 16:5324-5333.

$\mathrm{H}$ rabetova S, Sacktor TC (1997) L ong-term potentiation and long-term depression are induced through pharmacologically distinct NM DA receptors. Neurosci L ett 226:107-110.
H rabetova S, M onaghan D, Sacktor TC (1998) LTP and LTD are induced through two distinct NMDA-receptor subpopulations. Eur J Neurosci 10[Suppl 10]:26.

I keda K, Nagasawa M, M ori H, A raki K, Sakimura K, Watanabe M, Inoue $Y$, M ishina M (1992) C loning and expression of the epsilon 4 subunit of the N M DA receptor channel. FEBS L ett 313:34-38.

I shii T, M oriyoshi $K$, Sugihara $H$, Sakurada $K, K$ adotani $H$, Y okoi M, A kazawa C, Shigemoto R, M izuno N, M asu M, Nakanishi S (1993) M olecular characterization of the family of the $N$-methyl-D-aspartate receptor subunits. J Biol Chem 268:2836-2843.

Kentros C, H argreaves E, H awkins R D, K andel ER, Shapiro M, M uller RV (1998) A bolition of long-term stability of new hippocampal place cell maps by N M DA receptor blockade. Science 280:2121-2126.

K irkwood A, D udek SM, Gold J T, A izenman CD, Bear M F (1993) Common forms of synaptic plasticity in the hippocampus and neocortex in vitro. Science 260:1518-1521.

K irson ED, Schirra C, K onnerth A, Y aari Y (1999) Early postnatal switch in magnesium sensitivity of N M DA receptors in rat CA 1 pyramidal cells. J Physiol (L ond) 521:99-111.

Lisman J (1989) A mechanism for the $\mathrm{Hebb}$ and the non-Hebb processes underlying learning and memory. Proc Natl A cad Sci U SA 86:9574-9578.

Malenka RC (1994) Synaptic plasticity in the hippocampus: LTP and LTD. C ell 78:535-538.

M ayford M, Wang J, K andel E, O 'D ell T (1995) C aM K II regulates the frequency-response function of hippocampal synapses for the production of both LTD and LTP. C ell 81:891-904.

M onyer H, Sprengel R, Schoepfer R, Herb A, H iguchi M, L omeli $H$, Burnashev N, Sakmann B, Seeburg P (1992) Heteromeric N M DA receptors: molecular and functional distinction of subtypes. Science 256:1217-1221.

M onyer H, Burnashev N, L aurie D, Sakmann B, Seeburg P (1994) Developmental and regional expression in the rat brain and functional properties of four N M DA receptors. Neuron 12:529-540.

M onaghan DT (1993) Autoradiographic analysis of excitatory amino acid receptors. In: R eceptor autoradiography: principles and practice (Wharton J, Polak J M, eds), pp 171-193. N ew Y ork: Oxford UP.

M onaghan DT, L arson H (1997) N R 1 and N R 2 subunit contributions to NMDA receptor channel blocker pharmacology. J Pharmacol Exp Ther 280:614-620.

M onaghan DT, A ndalora VJ, Skifter D (1998) M olecular determinants of NMDA receptor pharmacological diversity. Prog Brain Res 116:158-177.

M ulkey R M , M alenka R C (1992) M echanisms underlying induction of homosynaptic long-term depression in area CA 1 of the hippocampus. Neuron 9:967-975.

Scherzer CR, L andwehrmeyer G B, Kerner JA, Counihan TJ, K osinski $C M$, Standaert DG, Daggett LP, Velicelebi G, Penney J B, Y oung A B (1998) Expression of $N$-methyl-D-aspartate receptor subunit $\mathrm{mR}$ NA s in the human brain: hippocampus and cortex. J Comp Neurol 390:75-90.

Wenzel A, Villa M, Mohler H, Benke D (1996) Developmental and regional expression of N M DA receptor subtypes containing the N R 2D subunit in rat brain. J Neurochem 66:1240-1248.

Y ang SN, Tang Y G, Z ucker R S (1999) Selective induction of LTP and LTD by postsynaptic [C $\mathrm{a}^{2+}$ ]i elevation. J Neurophysiol 81:781-787. 